\title{
KARAKTERISTIK FRAKSI AKTIF BIOPIGMEN FUKOSANTIN RUMPUT LAUT COKELAT SEBAGAI ANTIOKSIDAN DAN UV-PROTECTOR
}

\author{
Asadatun Abdullah*, Nurjanah, Ade Irma Suryani Nasution \\ Departemen Teknologi Hasil Perairan, Fakultas Perikanan dan Ilmu Kelautan \\ Institut Pertanian Bogor, Kampus IPB Darmaga, Jalan Agatis, Bogor 16680 Jawa Barat \\ Telepon (0251) 8622909-8622906, Faks. (0251) 8622915 \\ Diterima: 21 Januari 2021/Disetujui: 30 April 2021 \\ *Korespondensi: asabdullah@apps.ipb.ac.id
}

Cara sitasi: Abdullah A, Nurjanah, Nasution AIS. 2021. Karakteristik fraksi aktif biopigmen fukosantin rumput laut cokelat sebagai antioksidan dan UV-protector. Jurnal Pengolahan Hasil Perikanan Indonesia. 24(1): 131-147.

\begin{abstract}
Abstrak
Rumput laut cokelat Padina sp. dan Sargassum sp. mengandung pigmen, di antaranya pigmen fukosantin sebagai antioksidan, antikarsinogenik, dan anti-UV. Tujuan penelitian ini menentukan konsentrasi pelarut aseton optimal mendapatkan rendemen fukosantin tertinggi dengan antiokisidan, total fenol, dan nilai SPF terbaik, serta mengidentifikasi profil senyawa dengan LC-MS/MS. Tahapan penelitian yaitu perendaman dalam DMSO 10\% lalu diekstrak dengan pelarut aseton $80 \%$ dan $90 \%$. Analisis antioksidan metode DPPH, FRAP, dan ABTS dengan hasil berturut-turut yaitu Padina sp. sebesar 153,55 ppm, 94,22 $\mu \mathrm{mol} \mathrm{Fe}{ }^{2+} / \mathrm{g}, 66,43 \mathrm{ppm}$ (aseton 80\%) dan 65,76 ppm, 93,11 $\mu \mathrm{mol} \mathrm{Fe}{ }^{2+} / \mathrm{g}, 78,33 \mathrm{ppm}$ (aseton 90\%); Sargassum sp. sebesar 131,37 ppm, 103,67 $\mu \mathrm{mol} \mathrm{Fe}{ }^{2+} / \mathrm{g}, 57,29 \mathrm{ppm}$ (aseton 80\%) dan 103,24 ppm, 71,72 $\mu \mathrm{mol} \mathrm{Fe}{ }^{2+} / \mathrm{g}, 61,45 \mathrm{ppm}$ (aseton 90\%). Total fenol pada Padina sp. sebesar 675,48 mg GAE/g (aseton 80\%) dan 852,90 mg GAE/g (aseton 90\%); Sargassum sp. sebesar 565,81 mg GAE/g (aseton 80\%) dan 135,16 mg GAE/g (aseton 90\%). Nilai SPF konsentrasi optimal $50 \mathrm{mg} / \mathrm{mL}$ yaitu Padina sp. sebesar 9,08 (aseton $80 \%$ ) dan 17,10 (aseton 90\%); Sargassum sp. sebesar 7,56 (aseton 80\%) dan 3,56 (aseton 90\%). Aseton 80\% adalah pelarut optimal menghasilkan fraksi aktif fukosantin terbaik dengan rendemen, antioksidan, total fenol, dan nilai SPF tertinggi.
\end{abstract}

Kata Kunci : Padina sp., Sargassum sp., SPF, total fenol

\section{Characteristics of Fucoxanthin's Active Fraction from Brown Seaweeds Biopigments as Antioxidants and UV Protectors}

\begin{abstract}
Padina sp. and Sargassum sp. contains pigment namely fucoxanthins and have antioxidants, anticarcinogenic, and anti-UV. The objectives of this study were to determine the optimal concentration of acetone to produce the best fucoxanthin active fraction with antioxidant, total phenol, SPF value functions as well as to identify the profile of the compound with LC-MS/MS. Seaweeds were immersed in 10\% DMSO before extracted with $80 \%$ and $90 \%$ acetone solvent. The results of antioxidant DPPH, FRAP, and ABTS were Padina sp. of 153.55 ppm, $94.22 \mu \mathrm{mol} \mathrm{Fe} 2+/ \mathrm{g}, 66.43 \mathrm{ppm}$ (80\% acetone) and $65.76 \mathrm{ppm}, 93.11 \mu \mathrm{mol} \mathrm{Fe} 2+/ \mathrm{g}$, 78.33 ppm (90\% acetone); Sargassum sp. of 131.37 ppm, $103.67 \mu \mathrm{mol}$ Fe2+/g, 57.29 ppm (80\% acetone) and $103.24 \mathrm{ppm}, 71.72 \mu \mathrm{mol} \mathrm{Fe} 2+\mathrm{g}, 61.45 \mathrm{ppm}$ (90\% acetone). Total phenol of $80 \%$ dan $90 \%$ acetone from Padina sp. were $675.48 \mathrm{mg} \mathrm{GAE} / \mathrm{g}$ and $852.90 \mathrm{mg}$ GAE/g; Sargassum sp. of $565.81 \mathrm{mg}$ GAE/g and $135.16 \mathrm{mg}$ GAE/g. SPF value with optimal concentration $50 \mathrm{mg} / \mathrm{mL}$ had resulted of Padina sp. by 9.08 ( $80 \%$ acetone) and 17.10 (acetone 90\%); Sargassum sp. of 7.56 (acetone 80\%) and 3.56 (acetone 90\%). Acetone $80 \%$ is the optimal solvent to produce the best fucoxanthin active fraction with the highest characteristics of yield, antioxidant activity, total phenol content, and SPF value.
\end{abstract}

Keywords:_Padina sp., Sargassum sp., SPF, total phenol 


\section{PENDAHULUAN}

Rumput laut cokelat memiliki kandungan polifenol dengan jumlah yang tinggi (Wu et al. 2014). Pemanfaatan rumput laut cokelat di Indonesia pada bidang kosmetik perlu dilakukan untuk meningkatkan nilai tambah produk. Limantara dan Heriyanto (2010) menyatakan bahwa warna talus rumput laut cokelat berasal dari campuran pigmen golongan klorofil dan pigmen golongan karotenoid. Pigmen fukosantin merupakan pigmen utama dari golongan karotenoid yang terdapat dalam rumput laut cokelat dan diperkirakan mencapai lebih dari $10 \%$ dari total produksi karotenoid alami dari biota lainnya.

Pemanfaatan rumput laut sebagai bahan baku untuk kosmetik telah dilakukan di antaranya adalah:senyawa bioaktif rumput laut dan ampas teh sebagai antibakteri dalam formula masker wajah (Nurjanah et al. 2018), kandungan senyawa bioaktif rumput laut Padina australis dan Eucheuma cottonii sebagai bahan baku krim tabir surya (Maharani et al. 2017), rasio bubur rumput laut E.cottonii dan Sargassum sp. sebagai formula krim tabir surya (Luthfiyana et al. 2016), identifikasi senyawa bioaktif rumput laut Sargassum sp. and E. cottonii doty sebagai bahan baku krim tabir surya (Nurjanah et al. 2017), aktivitas penghambatan tirosinase dan antioksidan serbuk rumput laut dari Sargassum plagyophyllum segar dan kering (Arifanti et al. 2017), profil fenolik dan aktivitas antioksidan dari ekstrak rumput laut Turbinaria conoides dan E. cottonii (Yanuarti et al. 2017), kandungan senyawa bioaktif bubur rumput laut S.plagyophyllum dan E. cottonii sebagai bahan baku krim pencerah kulit (Dolorosa et al. 2017), karakteristik bubur rumput laut E. cottonii dan T. conoides sebagai bahan baku masker peel off (Nurjanah et al. 2019)

Fukosantin memiliki aktivitas biologis yang tinggi dan telah menarik banyak perhatian untuk diteliti lebih lanjut. Rumput laut Padina sp. dan Sargassum sp. memiliki kandungan fukosantin yang tinggi (Noviendri et al. 2011, Limantara dan Heriyanto 2011). Sudhakar et al. (2013) dan Fernandes (2018) menunjukkan bahwa aseton $90 \%$ lebih baik untuk mengekstrak fukosantin dibandingkan aseton 100\% dan etanol p.a. Fukosantin memiliki aktivitas antioksidan (Narayani et al. 2016), antibakteri (Renhoran et al. 2017), antikanker (Nursid et al. 2016), antifungi (Khaled et al. 2012), anti-UV karena dapat menghambat pembentukan ROS (reactive oxygen species) intraseluler dan kerusakan DNA yang disebabkan oleh paparan radiasi UV (Lestari dan Mita 2017). Kandungan antioksidan dan antikarsinogenik yang terdapat dalam fukosantin dapat dijadikan campuran dalam bahan baku farmasi maupun kosmetik sebagai protector UV. Pemanfaatan fukosantin dalam bidang kosmetik khususnya sebagai protector UV diharapkan dapat meningkatkan kesehatan konsumen dengan menjaga konsumen dari pengaruh radikal bebas yang dapat menyebabkan berbagai macam penyakit degeneratif terutama kanker kulit.

Sinar UVB merupakan sinar yang paling berbahaya bagi manusia karena termasuk sumber radikal bebas bersifat karsinogenik karena dapat diserap oleh DNA tubuh sehingga terjadin kerusakan DNA yang akan berpotensi menjadi mutagen. Oleh karena itu, kulit perlu dilindungi dari paparan sinar UV untuk mencegah terjadinya kanker kulit yang tidak menimbulkan efek samping yang negatif. Protector UV yang terbuat dari bahan alami yang terjamin lebih aman untuk pemakaian skala panjang. Bahan alami yang umum digunakan sebagai UV protection selain tumbuhan terestrial yaitu tumbuhan laut berupa rumput laut cokelat spesies Padina sp. dan Sargassum sp. yang kaya biopigmen sebagai bahan baku untuk pembuatan sediaan antioksidan dan UV protector belum banyak dilakukan hingga kini di Indonesia. Adapun tujuan penelitian ini adalah menentukan konsentrasi pelarut aseton optimal untuk menghasilkan fraksi aktif fukosantin dengan rendemen tertinggi yang memiliki aktivitas antioksidan terbaik, serta yang memiliki kandungan total fenol dan nilai Sun Protection Factor (SPF) tertinggi dari rumput laut Padina sp. dan Sargassum sp, serta mengidentifikasi profil komponen senyawa rumput laut Padina sp dan Sargassum sp dengan LC-MS/MS. 


\section{BAHAN DAN METODE Bahan dan Alat}

Bahan utama yang digunakan dalam penelitian ini yaitu rumput laut Padina sp. dan Sargassum sp. yang diperoleh dari Perairan Aceh dalam bentuk kering kemudian dihaluskan menjadi serbuk sebanyak $25 \mathrm{~g}$. Bahan yang digunakan dalam proses ekstraksi yaitu DMSO (Merck) dan aseton (Merck). Bahan yang digunakan sebagai eluen pada uji kromatografi kolom adalah kloroform (Merck) dan etanol p.a. (Merck), serta silika gel G60 (230-400 mesh, Merck). Bahan yang digunakan untuk analisis kuantitatif total fenol yaitu $\mathrm{Na}_{2} \mathrm{CO}_{3}$ (Merck) dan reagen FolinCiocalteu. Bahan yang digunakan untuk analisis antioksidan yaitu asam askorbat (Merck), DPPH (Sigma), $\mathrm{CuCl}_{2} \cdot 2 \mathrm{H}_{2} \mathrm{O} 0,01$ $\mathrm{M}$ (Merck), neukoprin etanolik 0,0075 M (Sigma), bufer amonium asetat $\mathrm{pH} 71 \mathrm{M}$ (Samarth), TPTZ (Sigma), $\mathrm{CH}_{3} \mathrm{COONa}$ (Merck), $\mathrm{CH}_{3} \mathrm{COOH}$ (Merck), $\mathrm{FeCl}_{3} \cdot 6 \mathrm{H}_{2} \mathrm{O}$, $\mathrm{FeSO}_{4} \cdot 7 \mathrm{H}_{2} \mathrm{O}$ (Merck), ABTS, dan kalium persulfat.

Alat yang digunakan dalam peneilitian ini yaitu kain blacu, kertas saring, blender, timbangan analitik (Sartorius TE64, Jerman), sudip, gelas piala (Pyrex), tabung reaksi (Pyrex), labu erlenmeyer $500 \mathrm{~mL}$ (Pyrex), gelas ukur (Pyrex), pipet kapiler, pipet volumetrik (Herma), botol vial, botol serum, mikropipet (Gilson), lembaran tipis aluminium, alat kocok edar (Wisd SHO-1D), kromatografi lapis tipis (Merck), evaporator putar vakum (Butchi Rotavapor R-100), kromatografi kolom (Pyrex), vorteks, dan spektrofotometer UV-Vis.

\section{Metode Penelitian}

Penelitian terdiri dari beberapa tahapan antara lain tahap preparasi, ekstraksi, elusi dengan kromatografi kolom, dan tahap analisis.

Preparasi dan ekstraksi rumput laut cokelat (modifikasi Seely et al. (1972) dan Sudhakar et al. (2013))

Proses preparasi sampel dilakukan dengan mengeringkan rumput laut menggunakan angin selama 24-48 jam kemudian dihaluskan menjadi serbuk menggunakan blender lalu disaring menggunakan saringan sehingga ukuran partikel serbuk rumput laut sebesar 25 mesh. Serbuk rumput laut ditimbang seberat 2 g untuk dianalisis kadar air dan ditimbang seberat $25 \mathrm{~g}$ lalu direndam dalam larutan DMSO 10\% 1:4 (w/v) selama 10 menit. Sampel kemudian diekstrak dengan dua jenis pelarut yaitu $80 \%$ dan $90 \%$ aseton masing-masing dengan perbandingan 1:8 (w/v). Ekstraksi dilakukan dengan menggunakan alat kocok edar (rotary evaporator), kemudian hasil ekstrak disaring menggunakan kertas saring hingga menghasilkan filtrat dan residu. Filtrat hasil ekstraksi kemudian dievaporasi dengan evaporator putar dengan suhu $40-50{ }^{\circ} \mathrm{C}$. Hasil ekstrak disimpan pada suhu dingin dan terhindar dari cahaya. Rendemen dihitung sebagai persentase bobot ekstrak yang didapat dari sampel awal. Rendemen dihitung sebagai persentase bobot ekstrak yang didapat dari sampel awal.

\section{Separasi komponen pigmen dengan kromatografi lapis tipis (Suryana 2010)}

Separasi komponen pigmen dengan KLT diawali dengan menyiapkan eluen pengembang yaitu kloroform : etanol (7:3) dalam bejana kromatografi. Ekstrak kemudian ditotolkan dengan pipet kapiler pada plat KLT silika gel dengan jarak $1 \mathrm{~cm}$ dari tepi bawah pelat. Pelat KLT kemudian dimasukkan ke dalam bejana kromatografi yang sudah berisi eluen pengembang lalu dielusi hingga berjarak $1 \mathrm{~cm}$ dari tepi atas pelat. Cara menentukan nilai Rf dengan menghitung jarak perbandingan bercak sampel dengan eluen.

\section{Fraksinasi komponen pigmen dengan kromatografi kolom (modifikasi Sudhakar et al. 2013)}

Sebelum dimulai proses isolasi, kolom kaca dibersihkan dengan akuades dan eluen yaitu pelarut kloroform dan etanol (7:3) lalu disumbat dengan wol kaca atau kapas. Pencampuran gel silika (70-270 mesh) dengan eluen dalam kolom lalu diaduk secara berkelanjutan. Kolom dibiarkan selama sehari penuh agar dapat mengikat silika dengan benar dan padat, kemudian masukkan $1 \mathrm{~g}$ sampel ekstrak yang telah diencerkan dengan 
pelarut 1:4 (b/v) ke dalam kolom. Ketika ekstrak kasar telah terikat di atas kolom silika, eluen kloroform dan etanol (7:3) ditambahkan ke dalam kolom secara terus menerus. Fraksi yang dihasilkan lalu disimpan dalam botol gelap dengan suhu $4-10{ }^{\circ} \mathrm{C}$. Hasil fraksi dipisahkan sesuai warna dan nilai Rf untuk menentukan jenis pigmennya.

\section{Uji alkaloid (modifikasi Vinod et al. 2010)}

Uji alkaloid dilakukan berdasarkan metode Meyer, Wagner, dan Dragendroff. Ekstrak sampel sebanyak $50 \mathrm{mg}$ ditambahkan $3 \mathrm{~mL}$ kloroform dan 3 tetes amoniak. Fraksi kloroform dipisahkan dan diasamkan dengan 10 tetes $\mathrm{H}_{2} \mathrm{SO}_{4} 2 \mathrm{M}$. Fraksi asam diambil, kemudian ditambahkan pereaksi Meyer, Wagner, Dragendroff. Adanya alkaloid ditandai dengan terbentuknya endapan putih oleh pereaksi Meyer, endapan cokelat oleh pereaksi Wagner, dan endapan merah oleh pereaksi Dragendroff.

\section{Uji saponin (modifikasi Vinod et al. 2010)}

Ekstrak sampel sebanyak $50 \quad \mathrm{mg}$ dimasukkan ke dalam gelas piala kemudian ditambahkan $50 \mathrm{~mL}$ air panas dan didihkan selama 5 menit, setelah itu disaring. Uji ini dilakukan dengan pengocokan $10 \mathrm{~mL}$ filtrat dalam tabung reaksi bertutup selama 10 detik lalu dibiarkan selama 10 menit. Adanya saponin ditunjukan dengan terbentuknya buih atau busa yang stabil.

\section{Uji flavonoid (modifikasi Vinod et al. 2010)}

Ekstrak sampel sebanyak $50 \mathrm{mg}$ ditambahkan metanol 30\% sampai terendam dan dipanaskan selama 5 menit. Setelah dipanaskan, ekstrak disaring sehingga diperoleh filtratnya. Filtrat ekstrak kemudian ditambahkan 1 tetes $\mathrm{NaOH}$ 10\%. Adanya flavonoid ditunjukkan dengan terbentuknya warna merah pada filtrat setelah ditambahkan $\mathrm{NaOH} 10 \%$.

\section{Uji tanin dan fenol (modifikasi Vinod et al. 2010)}

Ekstrak sampel sebanyak $0,1 \quad \mathrm{~g}$ ditambahkan $2 \mathrm{~mL}$ air kemudian dididihkan selama 2 menit. Ekstrak lalu disaring dan filtratnya ditambah 1 tetes $\mathrm{FeCl}_{3} 1 \%(\mathrm{~b} / \mathrm{v})$. Warna biru tua atau hitam kehijauan menunjukkan adanya tanin. Warna biru kehijauan menunjukkan adanya fenol.

\section{Uji steroid dan triterpenoid (modifikasi Vinod et al. 2010)}

Ekstrak sampel sebanyak $50 \mathrm{mg}$ ditambah asam asetat anhidrida sampai terendam dalam tabung reaksi dan dipanaskan selama 5 menit. Setelah dipanaskan, campuran ekstrak didinginkan dan kemudian ditambahkan 1 tetes $\mathrm{H}_{2} \mathrm{SO}_{4}$ pekat melalui sisi tabung. Adanya steroid dan triterpenoid ditandai dengan terbentuknya cincin berwarna cokelat pada dua lapisan cairan. Warna hijau pada lapisan atas menunjukkan adanya steroid, sedangkan warna merah pada lapisan bawah menunjukkan adanya triterpenoid.

\section{Metode DPPH (1,1-difenil-2-pikrilhidrazil) (Modifikasi Boeing et al. 2014)}

Ekstrak sampel sebanyak 4,5 mL yang telah diencerkan ditambahkan ke 0,5 mL 0,1 $\mathrm{mM}$ DPPH dengan pelarut etanol lalu divorteks selama 30 detik. Kedua campuran diinkubasi dalam kondisi gelap selama 30 menit. Pengujian dilakukan dengan konsentrasi sampel 50, 75, 100, 125, 150 dan $175 \mathrm{ppm}$. Kontrol positif menggunakan asam askorbat dengan konsentrasi 1, 2, 3, 4, 5 dan 6 ppm. Pengukuran absorbansi dengan panjang gelombang $517 \mathrm{~nm}$ menggunakan spektrofotometer. Aktivitas antioksidan masing-masing sampel dinyatakan dengan persentase penghambatan radikal bebas sampel.

\section{Metode cupric reducing antioxidant capacity (CUPRAC) (Modifikasi Apak et al. 2008)}

Ekstrak sampel sebanyak $0,3 \mathrm{~mL}$ dilarutkan dalam etanol $99,9 \%$ lalu ditambahkan dengan $1 \mathrm{~mL} \mathrm{CuCl} \cdot 2 \mathrm{H}_{2} \mathrm{O} 0,01$ 
M, $1 \mathrm{~mL}$ neukoprin etanolik 0,0075 M, $1 \mathrm{~mL}$ bufer amonium asetat pH $71 \mathrm{M}$ dan 0,8 mL akuades. Campuran tersebut di-vorteks lalu diinkubasi pada suhu ruang dalam keadaan gelap selama 30 menit. Nilai absorbansi diukur pada panjang gelombang $450 \mathrm{~nm}$. Kurva kalibrasi dibuat menggunakan standar larutan asam askorbat dengan berbagai konsentrasi.

\section{Metode ferric reducing antioxidant power (FRAP) (Modifikasi Kumar et al. 2014)}

Preparasi reagen FRAP berupa bufer asetat $300 \mathrm{mM}\left(8 \mathrm{~mL} \mathrm{CH}_{3} \mathrm{COONa}\right.$ dan $92 \mathrm{~mL}$ $\left.\mathrm{CH}_{3} \mathrm{COOH}\right) \mathrm{pH} 3,6,10 \mathrm{mM}$ larutan TPTZ (2,4,6-tripydridyl-striazine) dalam $40 \mathrm{mM} \mathrm{HCl}$ dan $\mathrm{FeCl}_{3} \cdot 6 \mathrm{H}_{2} \mathrm{O} 20 \mathrm{mM}$. Larutan disiapkan dalam keadaan segar dengan mencampurkan $35 \mathrm{~mL}$ bufer asetat, $3,5 \mathrm{~mL}$ TPTZ dan $3,5 \mathrm{~mL}$ larutan $\mathrm{FeCl}_{3} \cdot 6 \mathrm{H}_{2} \mathrm{O}$. Pengukuran absorbansi menggunakan $100 \mu \mathrm{l}$ sampel, $900 \mu \mathrm{l}$ akuades dan $2000 \mu \mathrm{l}$ reagen FRAP. Campuran tersebut divorteks lalu diinkubasi dalam waterbath selama 30 menit pada suhu $37{ }^{\circ} \mathrm{C}$. Nilai absorbansi diukur pada panjang gelombang $593 \mathrm{~nm}$. Kurva standar dibuat menggunakan standar larutan $\mathrm{FeSO}_{4} \cdot 7 \mathrm{H}_{2} \mathrm{O}$ dengan berbagai konsentrasi.

\section{Metode ABTS (2, 2'-azinobis-(3- ethylbenzothiazoline-6-sulfonic acid)) (Modifikasi Re et al. 1999)}

Sebelum dilakukan uji antioksidan pada sampel, perlu dilakukan persiapan reagen radikal ABTS yaitu dengan menyiapkan 7,4 mM larutan ABTS dan 2,6 mM larutan kalium persulfat yang dibiarkan dalam ruangan gelap pada suhu ruang selama 18 jam. Pengukuran absorbansi menggunakan 1 mL ekstrak sampel dicampurkan dengan $1 \mathrm{~mL}$ reagen ABTS dan diukur absorbansinya pada panjang gelombang $750 \mathrm{~nm}$ setelah diinkubasi selama 10 menit.

\section{Analisis kuantitatif total fenol (Modifikasi Apostolidis dan Lee 2010)}

Ekstrak sampel $1 \mathrm{~mL}$ ditambahkan 1 $\mathrm{mL}$ etanol $99,9 \%$ dan $5 \mathrm{~mL}$ akuades lalu tambahkan $0,5 \mathrm{~mL}$ reagen Folin-Ciocalteu $50 \%$, dihomogenkan dan didiamkan selama 5 menit, lalu ditambahkan $1 \mathrm{~mL} \mathrm{Na}_{2} \mathrm{CO}_{3}$
$5 \%$, dihomogenkan dan didiamkan pada kondisi gelap selama \pm 60 menit. Standar yang digunakan dalam pengujian ini adalah asam galat. Pengukuran sampel dibaca pada panjang gelombang $725 \mathrm{~nm}$, dengan nilai absorbansi dikonversi ke dalam total fenol dinyatakan dalam mg GAE/g berat sampel.

\section{Analisis Nilai SPF (Modifikasi Petro 1981)}

Sampel diambil sebanyak 1 g lalu dilarutkan dalam etanol 99,9\% sebanyak 100 $\mathrm{mL}$ dicampur hingga homogen kemudian dibuat dengan berbagai konsentrasi. Langkah selanjutnya yaitu membuat kurva serapan uji dalam kuvet, dengan panjang gelombang 290-320 menggunakan etanol 99,9\% sebagai blanko dengan interval $10 \mathrm{~nm}$. Data yang didapat diolah dengan persamaan sebagai berikut.

$$
[\mathrm{AUC}]=\frac{\mathrm{Aa}+\mathrm{Ab}}{2} \times(\mathrm{dPb}-\mathrm{a})
$$

Keterangan:

$\mathrm{Aa}=$ Absorbansi pada panjang gelombang a $\mathrm{nm}$

$\mathrm{Ab}=$ Absorbansi pada panjang gelombang $\mathrm{b}$ $\mathrm{nm}$

$\mathrm{dPb}-\mathrm{a}=$ Selisih panjang gelombang $\mathrm{Ab}$ dan $\mathrm{Aa}$

Nilai total AUC dihitung dengan menjumlahkan semua nilai AUC pada tiap segmen panjang gelombang. Nilai SPF masing-masing konsentrasi ditentukan dengan menggunakan persamaan sebagai berikut.

$$
[\mathrm{AUC}]=\frac{\mathrm{Aa}+\mathrm{Ab}}{2} \times(\mathrm{dPb}-\mathrm{a})
$$

Keterangan:

$\lambda \mathrm{n}=$ Panjang gelombang terbesar

$\lambda 1=$ Panjang gelombang terkecil

\section{Analisis LC-MS/MS (Pan et al. 2012)}

Identifikasi fraksi aktif biopigmen fukosantin hasil fraksinasi dianalisis menggunakan alat LC-MS/MS dengan sistem LC Ultra Performance Liquid Chromatoghrapy (UPLC) pada mode mass spectrometry ESI (Elektro Spray Ionization) dan QTOF (Quadrupole Time of Flight Mass). Eluen yang digunakan adalah air (A) dan asetonitril p.a (B). Eluen diatur pada laju aliran total $0,3 \mathrm{~mL} /$ 
menit. Perangkat lunak masslynx mengolah hasil kromatogram menjadi berbentuk mass array. Data yang didapatkan kemudian diidentifikasi dengan menentukan massa molekul $(\mathrm{m} / \mathrm{z})$ dan mencari rumus molekul kemudian membandingkannya dengan rumus molekul dari senyawa bioaktif yang terdapat pada Chemistry Structure Database (Chemspider) (www.chemspider.com). Hasil data berupa rumus molekul, bentuk molekul, massa molekul, dan kelimpahan senyawa yang dihitung berdasarkan luas area peak yang terdeteksi pada kromatogram.

\section{HASIL DAN PEMBAHASAN \\ Kadar Air dan Rendemen Ekstrak Rumput Laut Cokelat}

Padina sp. dan Sargassum sp. merupakan dua jenis rumput laut yang dikenal mengandung alginat, vitamin $\mathrm{C}$, vitamin $\mathrm{E}$ ( $\alpha$-tokoferol), mineral, karotenoid, klorofil, polisakarida sulfat, asam lemak, dan asam amino (Geraldino et al. 2005). Rumput laut memiliki kandungan air yang tinggi. Pengujian kadar air pada penelitian ini sesuai dengan SNI 01-2891-1992 dengan hasil nilai kadar air dari Padina sp. sebesar 6,075 $\pm 0,06 \%$ lebih rendah dibandingkan nilai kadar air dari Sargassum sp. sebesar 7,525 $\pm 0,33 \%$. Kedua sampel dikatakan baik dan dapat disimpan dalam waktu yang lama karena kadar air yang kurang dari $10 \%$ dapat menghambat proses pembusukan yang disebabkan oleh mikroorganisme (BPOM 2004). Diachanty et al. (2017) menunjukkan bahwa kadar air dari S. polycystum dan P. minor kering sebesar $24-31 \%$. Perbedaan kadar air dari rumput laut tersebut disebabkan oleh perbedaan habitat sampel, lama serta proses pengeringan rumput laut. Rendemen ekstrak kasar sampel Padina sp. dan Sargassum sp. dengan konsentrasi pelarut aseton yang berbeda dapat dilihat pada Figure 1.

Ekstrakkasar yang dihasilkan darimasingmasing sampel dengan konsentrasi pelarut yang berbeda menghasilkan karakteristik yang relatif sama. Ekstrak kasar berbentuk pasta dengan aroma yang khas. Warna dari ekstrak kasar yaitu hijau kecokelatan. Hasil rendemen penelitian ini sesuai dengan penelitian Wahyuni dan Widjanarko (2015) yang menunjukkan bahwa rendemen ekstrak rumput laut dengan aseton $90 \%$ lebih tinggi dibandingkan aseton 80\% karena pigmen karotenoid yang dominan dalam rumput laut cokelat sebagian besar bersifat non polar akan lebih banyak terekstrak pada pelarut non polar yaitu aseton $90 \%$ yang memiliki tingkat kenonpolaran lebih tinggi dibandingkan aseton $80 \%$. Penelitian Sudhakar et al. (2013) yang menyatakan bahwa Padina sp. memiliki kandungan total pigmen klorofil (klorofil a dan b) tertinggi dibandingkan rumput cokelat lainnya sehingga ketika diekstrak akan menghasilkan rendemen ekstrak yang lebih tinggi dibandingkan Sargassum sp. dengan pelarut yang sama.

\section{Kandungan Komponen Fitokimia Rumput Laut Cokelat}

Hasil uji fitokimia ekstrak kasar sampel Padina sp. dan Sargassum sp. dengan konsentrasi pelarut aseton yang berbeda dapat dilihat pada Table 1.

Table 1 menunjukkan bahwa secara umum komponen fitokimia yang terdapat

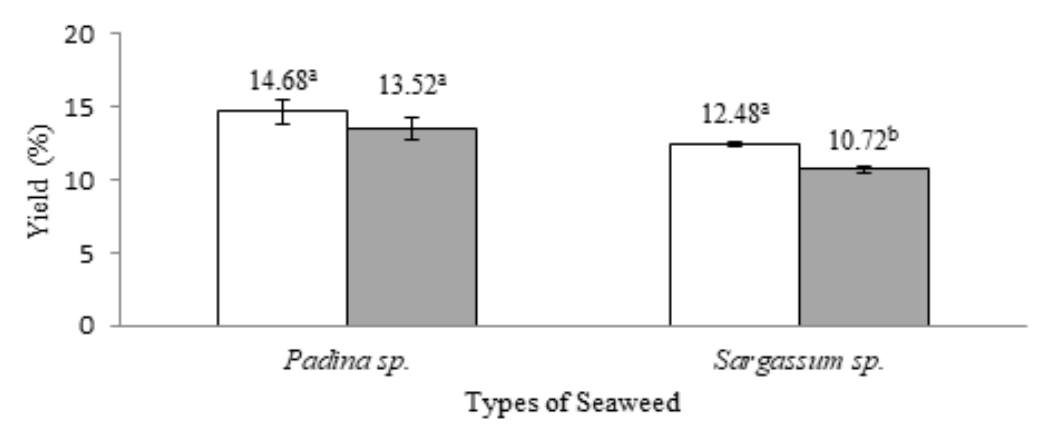

Figure 1 Yield of the crude extract of Padina sp. and Sargassum sp. using acetone solvent $90 \%$ $(\square)$ and acetone solvent $80 \%$ ( $\square$ ). Different superscript letters of the same seaweed species showed significant differences $(p<0.05)$ 
Table 1 Phytochemical test results of the crude extract of Padina sp. and Sargassum sp.

\begin{tabular}{|c|c|c|c|c|c|}
\hline \multirow[b]{2}{*}{ Phytochemical Test } & \multicolumn{2}{|c|}{ Acetone Solvent $80 \%$} & \multicolumn{2}{|c|}{ Acetone Solvent 90\% } & \multirow[b]{2}{*}{ Standard (color) } \\
\hline & $\begin{array}{l}\text { Padina } \\
\text { sp. }\end{array}$ & $\begin{array}{l}\text { Sargassum } \\
\text { sp. }\end{array}$ & $\begin{array}{l}\text { Padina } \\
\text { sp. }\end{array}$ & $\begin{array}{l}\text { Sargassum } \\
\text { sp. }\end{array}$ & \\
\hline \multicolumn{6}{|l|}{ Alkaloids } \\
\hline Meyer & - & + & + & + & Yellowish white precipitate \\
\hline Wagner & + & + & + & + & Brown precipitate \\
\hline Dragendorff & + & + & + & + & Red/orange precipitate \\
\hline Phenol Hydroquinone & + & + & + & + & $\begin{array}{l}\text { Forms a green-blueish green } \\
\text { color }\end{array}$ \\
\hline Flavonoids & + & + & + & + & $\begin{array}{l}\text { The color of amyl alcohol is } \\
\text { darker than underneath }\end{array}$ \\
\hline Tannins & + & + & + & + & $\begin{array}{l}\text { Formed a green-bluish green } \\
\text { color }\end{array}$ \\
\hline Saponin & + & + & + & + & $\begin{array}{l}\text { Forms a consistent foam } \\
\text { layer for } 10 \text { minutes }\end{array}$ \\
\hline Steroids & + & + & - & + & Greenish (top) \\
\hline Triterpenoids & - & - & - & - & Red (bottom) \\
\hline
\end{tabular}

Note $:(+)=$ detected, $(-)=$ non detected

dalam ekstrak Padina sp. dan Sargassum sp. adalah senyawa alkaloid, fenol, flavonoid, dan tanin. Hasil analisis menunjukkan bahwa senyawa alkaloid pada pereaksi Meyer tidak ditemukan pada Padina sp. dengan pelarut aseton $80 \%$, dan untuk senyawa steroid tidak ditemukan pada Padina sp. dengan pelarut aseton $90 \%$, serta tidak ditemukannya senyawa triterpenoid pada semua sampel. Hasil analisis fitokimia dipengaruhi oleh konsentrasi pelarut yang digunakan dalam ekstraksi (Egwaikhide dan Gimba 2007).

Senyawa alkaloid memiliki sifat fisik yang kurang tahan panas dan mempunyai kelarutan yang kecil dalam air, namun memiliki kelarutan yang lebih besar dalam pelarut yang bersifat murni sehingga terdeteksi dengan pelarut aseton $90 \%$. Senyawa steroid tidak ditemukan pada Padina sp. dengan pelarut aseton $90 \%$, serta tidak ditemukannya senyawa triterpenoid pada semua sampel sebab senyawa steroid dan triterpenoid memiliki gugus hidroksil yang termasuk gugus polar sehingga senyawa tersebut sedikit larut pada aseton yang termasuk pelarut semi polar (steroid), bahkan ada yang tidak larut sama sekali pada pelarut semi polar (triterpenoid) (Javanmardi et al. 2003). Perbedaan ini juga disebabkan adanya praperlakuan perendaman dengan DMSO $10 \%$ yang berfungsi mendenaturasi protein dan menembus membran sel sehingga dapat mengeluarkan senyawa aktif yang lebih banyak dari sampel (Seely et al. 1972).

\section{Separasi dan Fraksinasi Komponen Pigmen Ekstrak Rumput Laut Cokelat}

Analisis secara kualitatif untuk menentukan keberadaan fukosantin dalam rumput laut Padina sp. dan Sargassum sp. dilakukan dengan metode separasi menggunakan kromatografi lapis tipis (KLT). Fase gerak yang digunakan dalam penelitian ini adalah kloroform dan etanol (7:3), sedangkan fase diamnya ialah plat silika gel (Fernandes 2018). Visualisasi hasil separasi menggunakan plat KLT dapat dilihat pada Figure 2.

Figure 2 menunjukkan bahwa pola pemisahan ekstrak Padina sp. dan Sargassum sp. dengan bantuan eluen kloroform dan etanol (7:3) menunjukkan bahwa keempat sampel sama-sama menunjukkan 3 bercak yaitu berwarna oranye, hijau tua, dan hijau muda yang memiliki nilai Rf berbeda-beda. Nilai Rf dihitung berdasarkan perbandingan jarak 
Figure 2 Chromatogram analysis result of of crude extract, the Rf value of spot $1=0.96$; spot $2=0.94$; spot $3=0.91$.

tempuh eluen dengan sampel (Lampiran 4). Bercak pertama (1) pada kromatogram menunjukkan warna oranye dengan nilai Rf sebesar 0,98-0,96. Bercak kedua (2) menunjukkan warna hijau tua dengan nilai Rf sebesar 0,96-0,94. Bercak ketiga (3) menunjukkan warna hijau muda dengan nilai Rf sebesar 0,93-0,91. Hasil fraksinasi dapat dilihat pada Figure 3.

Figure 3 a menunjukkan bahwa biopigmen fukosantin diduga terdapat pada bagian atas kolom yang termasuk ke dalam fraksi 6 dengan ciri-ciri berwarna oranye kecokelatan dengan nilai $\mathrm{Rf}$ 0,25-0,28. Nilai Rf tersebut termasuk ke dalam fraksi aktif yang diduga mengandung fukosantin yang sesuai dengan beberapa penelitian yaitu nilai Rf pigmen fukosantin dari rumput laut Sargassum cinereum sebesar 0,26 (Narayani et al. 2016), juga nilai $\mathrm{Rf}$ pigmen fukosantin dari rumput laut Hijika fusiformis berkisar 0,25-0,28 (Yan et al. 1999), dan pigmen fukosantin dari rumput laut Sargassum ilicifolium memiliki

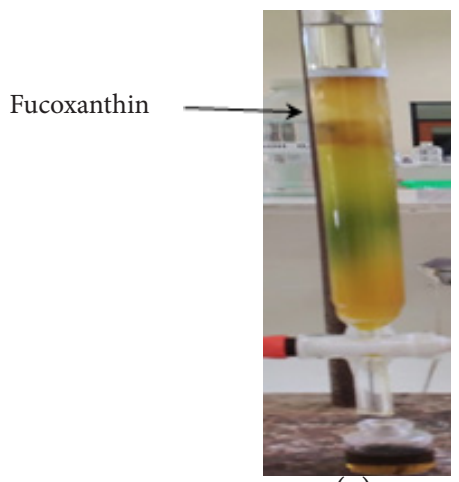

(a)
Rf sebesar 0,21 (Sudhakar et al. 2013). Hasil nilai Rf yang didapatkan menyimpulkan bahwa fraksi 6 dari hasil fraksinasi dengan kromatografi kolom diduga termasuk fraksi aktif fukosantin. Adapun rendemen fraksi dari proses fraksinasi sampel Padina sp. dan Sargassum sp. dengan konsentrasi pelarut aseton yang berbeda dapat dilihat pada Table 2.

Table 2. menunjukkan bahwa fraksi dengan rendemen tertinggi yaitu fraksi 6 yang diduga sebagai fraksi aktif fukosantin dengan warna oranye kecokelatan sebesar 0,25-0,35 $\mathrm{mg} / \mathrm{g}$. Sudhakar et al. (2013) menunjukkan bahwa rendemen pigmen fukosantin pada pelarut aseton $90 \%$ yaitu Sargassum sp. sebesar 0,09-0,23 mg/g lebih kecil dibandingkan Padina sp. sebesar $0,38 \mathrm{mg} / \mathrm{g}$, sedangkan rendemen pigmen fukosantin dengan pelarut aseton $100 \%$ yaitu Sargassum sp. sebesar 0,03-0,16 mg/g lebih kecil dibandingkan Padina sp. sebesar 0,12 mg/g. Hasil dari penelitian ini sesuai dengan literatur yang menunjukkan bahwa sampel Padina sp. lebih banyak mengandung pigmen fukosantin dibandingkan dengan sampel Sargassum sp. dan pelarut aseton dengan pengenceran lebih tinggi memiliki kandungan fukosantin yang banyak dibandingkan pelarut aseton murni.

\section{Aktivitas Antioksidan Ekstrak Kasar dan Fraksi Aktif Fukosantin Rumput Laut Cokelat}

Hasil uji aktivitas antioksidan pada ekstrak kasar sampel Padina sp. dan Sargassum sp. dengan konsentrasi pelarut aseton yang berbeda dapat dilihat pada Table 3 dan Table 4.

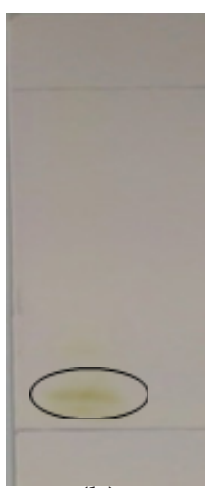

(b)

Figure 3 The fractionation process using column chromatography (a), and the determination of the $R f$ value of the active fraction of Fucoxanthin with TLC, the $R f$ value $=0.26$ (b) 
Table 2 Yield of the crude extract fraction of the sample by column chromatography

\begin{tabular}{|c|c|c|c|c|}
\hline Type of Sample & Fraction & Color & $\mathrm{Rf}$ & Yield (mg/g) \\
\hline \multirow{6}{*}{$\begin{array}{l}\text { Padina sp. } \\
\text { Acetone solvent } 80 \%\end{array}$} & 1 & Blackish yellow & 0.93 & 0.12 \\
\hline & 2 & Dark green & 0.89 & 0.14 \\
\hline & 3 & Gray green & 0.86 & 0.27 \\
\hline & 4 & Light green & 0.38 & 0.08 \\
\hline & 5 & Light yellow & 0.34 & 0.03 \\
\hline & 6 & Orange brown ${ }^{\star}$ ) & 0.23 & $0.35^{\mathrm{a}}$ \\
\hline \multirow{6}{*}{$\begin{array}{l}\text { Sargassum sp. } \\
\text { Acetone solvent } 80 \%\end{array}$} & 1 & Dark green & 0.95 & 0.23 \\
\hline & 2 & Gray green & 0.86 & 0.11 \\
\hline & 3 & Light green & 0.73 & 0.28 \\
\hline & 4 & Light yellow & 0.60 & 0.13 \\
\hline & 5 & Orange brown ${ }^{*}$ ) & 0.51 & 0.01 \\
\hline & 6 & Dark green & 0.25 & $0.30^{c}$ \\
\hline \multirow{6}{*}{$\begin{array}{l}\text { Padina sp. } \\
\text { Acetone solvent } 90 \%\end{array}$} & 1 & Dark green & 0.95 & 0.25 \\
\hline & 2 & Gray green & 0.86 & 0.12 \\
\hline & 3 & Light green & 0.78 & 0.22 \\
\hline & 4 & Light yellow & 0.57 & 0.08 \\
\hline & 5 & Orange brown ${ }^{*}$ ) & 0.50 & 0.02 \\
\hline & 6 & Dark green & 0.27 & $0.30^{\mathrm{b}}$ \\
\hline \multirow{6}{*}{$\begin{array}{l}\text { Sargassum sp. } \\
\text { Acetone solvent } 90 \%\end{array}$} & 1 & Dark green & 0.95 & 0.11 \\
\hline & 2 & Gray green & 0.91 & 0.14 \\
\hline & 3 & Light green & 0.89 & 0.28 \\
\hline & 4 & Light yellow & 0.69 & 0.15 \\
\hline & 5 & Orange brown ${ }^{*}$ ) & 0.65 & 0.04 \\
\hline & 6 & Dark green & 0.28 & $0.26^{\mathrm{d}}$ \\
\hline
\end{tabular}

Note $:^{*}$ It is suspected that the active fraction is Fucoxanthin, Different superscript letters showed significant differences $(p<0.05)$

Table 3 Antioxidant activity of crude extract Padina sp. and Sargassum sp. with DPPH and ABTS methods

\begin{tabular}{clrr}
\hline \multirow{2}{*}{ Solvent } & \multirow{2}{*}{ Sample } & \multicolumn{2}{c}{$\mathrm{IC}_{50}$ value $(\mathrm{ppm})$} \\
\cline { 3 - 4 } & & \multicolumn{1}{c}{ DPPH method } & \multicolumn{1}{c}{ ABTS method } \\
\hline \multirow{2}{*}{ Acetone 80\% } & Padina sp. & $104.72 \pm 0.06^{\mathrm{b}}$ & $101.78 \pm 0.08^{\mathrm{a}}$ \\
& Sargassum sp & $52.03 \pm 0.0^{\mathrm{d}}$ & $64.80 \pm 0.10^{\mathrm{c}}$ \\
& Padina sp. & $163.17 \pm 0.07^{\mathrm{a}}$ & $126.99 \pm 0.09^{\mathrm{a}}$ \\
Acetone 90\% & Sargassum sp & $127.75 \pm 0.0^{\mathrm{c}}$ & $102.48 \pm 0.10^{\mathrm{b}}$ \\
& Ascorbic Acid & $3.13 \pm 0.52$ & $3.59 \pm 0.30^{\mathrm{x}}$ \\
\hline
\end{tabular}

Note :Different superscript letters in the same column and seaweed species show a significant difference $(p<0.05)$ 
Table 4 Antioxidant activity of the crude extract of Padina sp. and Sargassum sp. With CUPRAC and FRAP methods

\begin{tabular}{clrr}
\hline Solvent & \multicolumn{1}{c}{ Sample } & $\begin{array}{c}\text { Antioxidant activity }(\mu \mathrm{g} / \mathrm{mL} \\
\text { ascorbic acid per g extract) } \\
\text { CUPRAC method }\end{array}$ & $\begin{array}{c}\text { Antioxidant activity }(\mu \mathrm{mol} \\
\mathrm{Fe} 2+\mathrm{g}) \text { of the FRAP method }\end{array}$ \\
\hline \multirow{2}{*}{ Acetone 80\% } & Padina sp. & $55.45 \pm 0.11^{\mathrm{a}}$ & $333.94 \pm 0.01^{\mathrm{a}}$ \\
& Sargassum sp & $68.90 \pm 0.06^{\mathrm{a}}$ & $210.05 \pm 0.01^{\mathrm{a}}$ \\
Acetone 90\% & Padina sp. & $40.05 \pm 0.07^{\mathrm{a}}$ & $475.61 \pm 0.09^{\mathrm{a}}$ \\
& Sargassum sp & $41.45 \pm 0.13^{\mathrm{a}}$ & $218.67 \pm 0.02^{\mathrm{a}}$ \\
& Ascorbic Acid & $169.20 \pm 0.02$ & $764.22 \pm 0.08$ \\
\hline
\end{tabular}

Note: Different superscript letters in the same column and seaweed species show a significant difference $(p<0.05)$.

Metode DPPH (2,2-difenil-1pikrilhidrazil) merupakan radikal bebas senyawa nitrogen. Larutan DPPH akan mengoksidasi senyawa dalam ekstrak sehingga akan mengubah warna ungu menjadi warna kuning. Aktivitas antioksidan ekstrak kasar sampel dari yang terendah hingga tertinggi yaitu Padina sp. aseton $90 \%<$ Sargassum sp. aseton $90 \%<$ Padina sp. aseton $80 \%<$ Sargassum sp. aseton $80 \%$. Aktivitas antioksidan ekstrak kasar menunjukkan bahwa sampel Sargassum sp. memiliki antioksidan yang tinggi dibandingkan Padina sp. Hal ini sesuai dengan beberapa penelitian yaitu Sudhakar et al. (2013) yang melakukan uji DPPH dengan hasil Sargassum sp. memiliki aktivitas inhibisi radikal bebas lebih tinggi daripada Padina sp. yaitu 29-57,67\%>24,67\% (aseton 90\%), 34\%>23\% (aseton 100\%), dan $43-47 \%>28 \%$ (etanol 90\%).

Metode ABTS merupakan pengujian antioksidan berdasarkan radikal anion $\mathrm{ABTS}^{+}$yang akan mereduksi senyawa ekstrak. Radikal ABTS diinkubasi dengan peroksidase (yaitu metmyoglobin dan $\mathrm{H}_{2} \mathrm{O}_{2}$ yang relatif stabil kation), kemudian $\mathrm{ABTS}^{+}$berinteraksi dengan Ferryl myoglobin dan menghasilkan warna biru-hijau yang stabil (Badarinath et al. 2010). Aktivitas antioksidan ekstrak kasar sampel dari yang terendah hingga tertinggi yaitu Padina sp. aseton $80 \%<$ Sargassum sp. aseton $80 \%<$ Sargassum sp. aseton $90 \%<$ Padina sp. aseton $90 \%$. Hasil penelitian sesuai dengan penelitian Dang et al. (2018) yang menunjukkan bahwa nilai aktivitas antioksidan ABTS Sargassum sp. sebesar 66,77-170,53 mg/g lebih besar dibandingkan
Padina sp. sebesar 46,65-139,64 mg/g. Perbedaan hasil $\mathrm{IC}_{50}$ dari ekstrak pada uji ABTS dipengaruhi oleh jenis sampel, pelarut, dan metode ekstraksi (Widyastuti 2010).

Metode CUPRAC (Cupric ion reducing antioxidant capacity) merupakan merupakan uji antioksidan yang menggunakan kompleks bis-neokuproin-tembaga (II) untuk mengoksidasi senyawa antioksidan yang terdapat dalam ekstrak sampel sehingga akan membentuk kompleks bis-neokuprointembaga (I). Aktivitas antioksidan ekstrak kasar sampel dari yang terendah hingga tertinggi yaitu Sargassum sp. aseton $80 \%<$ Sargassum sp. aseton $90 \%<$ Padina sp. aseton $80 \%<$ Padina sp. aseton $90 \%$. Hasil penelitian menunjukkan bahwa kisaran nilai aktivitas antioksidan ekstrak kasar sampel yaitu 56,3637-69,8864 mg/L yang jauh lebih besar dibandingkan penelitian Fung (2012) yang menunjukkan hasil antioksidan CUPRAC Undaria pinnatifida sebesar 1,20-1,41 mg/L untuk kondisi segar dan 0,78-0,93 mg/L untuk olahan. Perbedaan ini disebabkan oleh pelarut ekstrak yang digunakan, jenis ekstraksi, suhu ekstraksi, jenis dan habitat sampel.

Metode FRAP (ferric reducing antioxidant power) merupakan pengujian antioksidan yang didasarkan atas kemampuan senyawa antioksidan dalam mereduksi senyawa besi(III)-tripiridil-triazin menjadi besi(II)tripiridil-triazin pada $\mathrm{pH}$ 3,6 yang ditunjukkan dengan perubahan warna menjadi biru tua. Aktivitas antioksidan ekstrak kasar sampel dari yang terendah hingga tertinggi yaitu Sargassum sp. aseton $80 \%<$ Sargassum sp. aseton $90 \%<$ Padina sp. aseton $80 \%<$ Padina 
Table 5 Antioxidant activity of the active fraction of Fucoxanthin from Padina sp. and Sargassum sp. with various test methods

\begin{tabular}{clrrr}
\hline \multirow{2}{*}{ Solvent } & \multicolumn{1}{c}{ Sample } & $\begin{array}{c}\text { IC50 value }(\mathrm{ppm}) \\
\text { DPPH method }\end{array}$ & $\begin{array}{c}\text { Antioxidant activity } \\
(\mu \mathrm{mol} \text { Fe2 } / \mathrm{g}) \text { of the } \\
\text { FRAP method }\end{array}$ & $\begin{array}{c}\text { IC50 value }(\mathrm{ppm}) \\
\text { ABTS method }\end{array}$ \\
\hline \multirow{2}{*}{ Acetone 80\% } & Padina sp. & $153.55 \pm 0.03^{\mathrm{a}}$ & $94.22 \pm 0.01^{\mathrm{a}}$ & $66.43 \pm 0.08^{\mathrm{a}}$ \\
& Sargassum sp & $131.37 \pm 0.02^{\mathrm{c}}$ & $103.67 \pm 0.22^{\mathrm{a}}$ & $57.29 \pm 0.07^{\mathrm{a}}$ \\
\multirow{2}{*}{ Acetone 90\% } & Padina sp. & $65.76 \pm 0.09 \mathrm{~b}$ & $93.11 \pm 0.04^{\mathrm{a}}$ & $78.33 \pm 0.05^{\mathrm{a}}$ \\
& Sargassum sp & $103.24 \pm 0.01 \mathrm{~d}$ & $71.72 \pm 0.02^{\mathrm{a}}$ & $61.45 \pm 0.02^{\mathrm{a}}$ \\
- & Ascorbic Acid & $3.35 \pm 0.45$ & $733.67 \pm 0.07^{\mathrm{x}}$ & $3.59 \pm 0.04$ \\
\hline
\end{tabular}

Note: Different superscript letters in the same column and seaweed species show a significant difference $(p<0.05)$.

sp. aseton $90 \%$. Hasil penelitan tidak sesuai dengan penelitian Diachanty et al. (2017) yang menunjukkan bahwa aktivitas antioksidan metode FRAP $S$. polycystum sebesar 105,357 $\mu \mathrm{mol}$ troloks/g ekstrak lebih besar dibandingkan $P$. minor sebesar $74,143 \mu \mathrm{mol}$ troloks/g ekstrak. Perbedaan ini disebabkan oleh beberapa faktor antara lain pelarut ekstrak yang digunakan, jenis ekstraksi, suhu ekstraksi, jenis dan habitat sampel. Adapun hasil uji aktivitas antioksidan fraksi aktif fukosantin sampel Padina sp. dan Sargassum sp. dengan konsentrasi pelarut aseton yang berbeda dapat dilihat pada Table 5 .

Metode DPPH (2,2-difenil-1pikrilhidrazil) merupakan radikal bebas senyawa nitrogen. Mekanisme kerja DPPH yaitu mengambil atom hidrogen yang terdapat dalam suatu senyawa melalui transfer elektron. Aktivitas antioksidan untuk fraksi aktif fukosantin dari yang terendah hingga tertinggi yaitu Padina sp. aseton $80 \%<$ Sargassum sp. aseton $80 \%<$ Sargassum sp. aseton $90 \%<$ Padina sp. aseton 90\%. Dang et al. (2018) menunjukkan bahwa aktivitas antioksidan dengan metode DPPH semakin tinggi dengan semakin bertambahnya konsentrasi fukosantin. Hasil penelitian tidak sesuai dengan literatur yang menunjukkan bahwa aktivitas antioksidan fukosantin dari sampel rumput laut Sargassum sp. lebih besar dibandingkan dengan Padina sp. yaitu 29,08209,50 mg/g ekstrak berbanding 22,42-138,15 $\mathrm{mg} / \mathrm{g}$ ekstrak. Perbedaan antara hasil penelitian dengan literatur disebabkan oleh perbedaan habitat sampel yaitu sampel literatur berasal dari Perairan Australia sedangkan sampel penelitian dari Perairan Aceh, Indonesia.

Metode ABTS merupakan pengujian antioksidan berdasarkan radikal anion $\mathrm{ABTS}^{+}$yang akan mereduksi senyawa ekstrak berdasarkan perubahan warna larutan dari biru menjadi bening atau putih. Radikal ABTS diinkubasi dengan peroksidase (yaitu metmyoglobin dan $\mathrm{H}_{2} \mathrm{O}_{2}$ yang relatif stabil kation), kemudian $\mathrm{ABTS}^{+}$berinteraksi dengan Ferryl myoglobin dan menghasilkan warna biru-hijau yang stabil (Badarinath et al. 2010). Aktivitas antioksidan untuk fraksi aktif fukosantin dari yang terendah hingga tertinggi yaitu Sargassum sp. aseton $90 \%<$ Padina sp. aseton $90 \%<$ Padina sp. aseton $80 \%<$ Sargassum sp. aseton $80 \%$. Dang et al. (2018) menunjukkan bahwa aktivitas antioksidan dengan metode ABTS semakin tinggi dengan semakin bertambahnya konsentrasi fukosantin. Hasil penelitian sesuai dengan literatur yang menunjukkan bahwa aktivitas antioksidan fukosantin dari sampel rumput laut Sargassum sp. lebih besar dibandingkan dengan Padina sp. yaitu 31,71$183,38 \mathrm{mg} / \mathrm{g}$ ekstrak berbanding 22,53-183 $\mathrm{mg} / \mathrm{g}$ ekstrak.

Metode FRAP (ferric reducing antioxidant power) merupakan pengujian antioksidan yang didasarkan atas kemampuan senyawa antioksidan dalam mereduksi senyawa besi(III)-tripiridil-triazin menjadi besi(II)-tripiridil-triazin pada $\mathrm{pH}$ 3,6 yang ditunjukkan dengan perubahan warna menjadi biru tua. Aktivitas antioksidan untuk fraksi aktif fukosantin dari yang terendah hingga tertinggi yaitu Sargassum sp. aseton $90 \%<$ Padina sp. aseton $90 \%<$ Padina sp. 
aseton $80 \%<$ Sargassum sp. aseton $80 \%$. Dang et al. (2018) menunjukkan bahwa aktivitas antioksidan dengan metode FRAP semakin tinggi dengan semakin bertambahnya konsentrasi fukosantin. Hasil penelitian tidak sesuai dengan literatur yang menunjukkan bahwa aktivitas antioksidan fukosantin dari sampel rumput laut Sargassum sp. lebih besar dibandingkan dengan Padina sp. yaitu 20,30-283,71 mg/g ekstrak berbanding 5,10$34,53 \mathrm{mg} / \mathrm{g}$ ekstrak. Perbedaan antara hasil penelitian dengan literatur disebabkan oleh perbedaan habitat sampel yaitu sampel literatur berasal dari Perairan Australia sedangkan sampel penelitian dari Perairan Aceh, Indonesia.

\section{Nilai Total Fenol Ekstrak Kasar dan Fraksi Aktif Fukosantin Rumput Laut Cokelat}

Analisis total fenol menggunakan metode Folin-Ciocalteu yang melibatkan asam galat dengan konsentrasi $10-70 \mathrm{mg} / \mathrm{L}$ yang digunakan sebagai standar pengukuran. Hasil uji kandungan total fenol dari ekstrak kasar dan fraksi aktif biopigmen fukosantin dapat dilihat pada Figure 4.

Hasil kandungan total fenol dari fraksi berbanding terbalik dengan ekstrak kasar yang menunjukkan bahwa pada pelarut aseton $80 \%$ total fenol Padina sp. lebih besar dibandingkan
Sargassum sp. yaitu 2733,55 $\pm 0,13 \mathrm{mg} \mathrm{GAE/g}$ berbanding $2169,03 \pm 0,05 \mathrm{mg} \mathrm{GAE} / \mathrm{g}$, sedangkan pada pelarut aseton $90 \%$ total fenol Padina sp. lebih kecil dibandingkan Sargassum sp. yaitu 2275,48 $\pm 0,08 \mathrm{mg} \mathrm{GAE} / \mathrm{g}$ berbanding 2764,19 $\pm 0,24 \mathrm{mg}$ GAE/g. Perbedaan ini disebabkan ketika masih dalam bentuk ekstrak kasar pelarut aseton 80\% lebih mampu mengekstrak senyawa fenolik dari Padina sp. dibandingkan Sargassum sp., sedangkan dengan pelarut aseton 90\% lebih mampu mengekstrak senyawa fenolik dari Sargassum sp. dibandingkan dari Padina sp. Hal ini menunjukkan bahwa Padina sp. membutuhkan suasana pelarut yang lebih polar untuk mengekstrak senyawa fenolik dibandingkan dengan Sargassum sp.

Semakin tinggi kandungan fenolik total maka semakin tinggi pula aktivitias antioksidannya. Hal ini disebabkan bahwa kadar total fenol merupakan dasar dilakukannya pengujian antioksidan karena senyawa fenolik diketahui berperan dalam mencegah oksidasi. Kandungan total fenol yang tidak berkorelasi dengan aktivitas antioksidan menunjukkan bahwa terdapat senyawa lain dalam ekstrak antara lain klorofil, karoteoid, flavonoid, alkaloid, tannin, dan steroid yang mempengaruhi aktivitasi antioksidan sesuai dengan uji fitokimia yang dilakukan sebelumnya (Table 1) (Tang 1991).

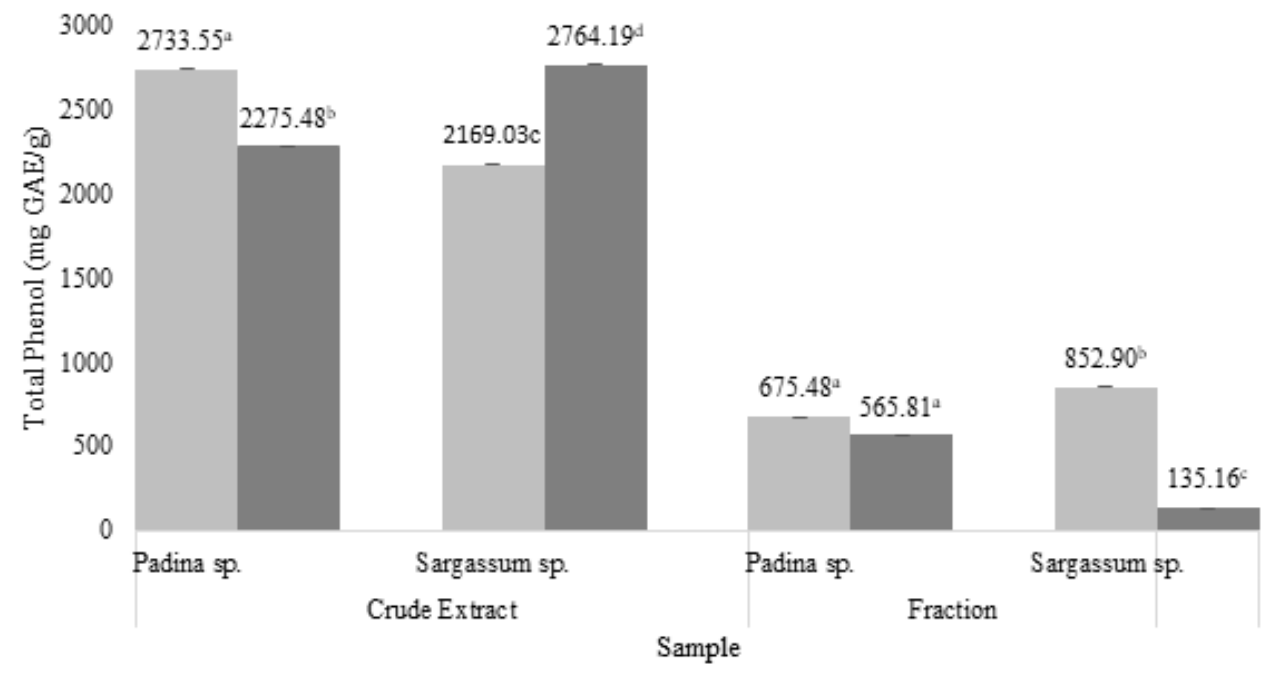

Figure 4 Total phenol of crude extract and active fraction of Fucoxanthin sample of Padina sp. and Sargassum sp. with acetone solvent 80\% $(\square)$ and acetone solvent $90 \%(\square)$. Different superscript letters in the same sample type showed significant differences $(\mathrm{p}<0.05)$ 
Table 6 SPF value of the active fraction of Fucoxanthin from Padina sp. and Sargassum sp.

\begin{tabular}{rrrrrr}
\hline $\begin{array}{c}\text { Concentration } \\
(\mathrm{mg} / \mathrm{mL})\end{array}$ & $\begin{array}{r}\text { Padina sp. } \\
\text { acetone 80\% }\end{array}$ & $\begin{array}{c}\text { Sargassum sp. } \\
\text { acetone } 80 \%\end{array}$ & $\begin{array}{r}\text { Padina sp. } \\
\text { acetone } 90 \%\end{array}$ & $\begin{array}{c}\text { Sargassum sp. } \\
\text { acetone } 90 \%\end{array}$ & $\begin{array}{c}\text { Commercial } \\
\text { sunscreen }(\text { SPF 30++) }\end{array}$ \\
\hline 5 & $1.68^{\mathrm{a}}$ & $1.89^{\mathrm{a}}$ & $1.46^{\mathrm{a}}$ & $1.21^{\mathrm{a}}$ & 3.19 \\
10 & $2.32^{\mathrm{a}}$ & $2.49^{\mathrm{a}}$ & $1.60^{\mathrm{a}}$ & $1.45^{\mathrm{a}}$ & 4.70 \\
30 & $3.00^{\mathrm{a}}$ & $3.16^{\mathrm{a}}$ & $2.95^{\mathrm{a}}$ & $1.95^{\mathrm{a}}$ & 12.00 \\
50 & $9.08^{\mathrm{a}}$ & $17.23^{\mathrm{b}}$ & $7.56^{\mathrm{a}}$ & $3.55^{\mathrm{c}}$ & 32.48 \\
\hline
\end{tabular}

Note: Different superscript letters in the same column and seaweed species show a significant difference $(p<0.05)$.

\section{Nilai SPF Ekstrak Kasar dan Fraksi Aktif Fukosantin Rumput Laut Cokelat \\ Nilai SPF (Sun Protection Factor)} dilakukan secara in vitro menggunakan spektrofotometri UV-Vis. Adapun hasil uji nilai SPF dari fraksi aktif fukosantin sampel Padina sp. dan Sargassum sp. dengan konsentrasi pelarut aseton yang berbeda dapat dilihat pada Table 6 .

Table 6 menunjukkan bahwa semakin tinggi konsentrasi sampel, maka semakin tinggi nilai absorbansinya sehingga semakin tinggi pula nilai SPFnya. Urutan dari nilai SPF terendah ke tertinggi yaitu Sargassum sp. aseton $90 \%<$ Padina sp. aseton $90 \%<$ Padina sp. aseton $80 \%<$ Sargassum sp. aseton $80 \%<$ tabir surya komersial.

Sami et al. (2015) menyatakan bahwa kategori pembagian nilai SPF yaitu nilai 2-4 termasuk proteksi minimal, nilai 4-6 termasuk proteksi sedang, nilai 6-8 termasuk proteksi ekstra, nilai 8-15 termasuk proteksi maksimal, dan nilai $>15$ termasuk proteksi ultra. Hasil penelitian Johnsen et al. (2014) menunjukkan bahwa penggunaan biopigmen fukosantin murni sebagai tabir surya dengan berbagai konsentrasi memiliki nilai SPF yang berbeda-beda. Fukosantin yang digunakan dengan konsentrasi $0,25 \mathrm{mg} / \mathrm{ml}, 0,55 \mathrm{mg} /$ $\mathrm{ml}$, dan $2,76 \mathrm{mg} / \mathrm{ml}$ memiliki nilai $\mathrm{SPF}$ berturut-turut sebesar 1,$26 ; 1,28$ dan 1,31 . Hal ini menunjukkan bahwa semakin tinggi konsentrasi fukosantin yang digunakan maka semakin tinggi pula nilai SPF.

\section{Senyawa Aktif Pigmen dan Non- Pigmen secara Semikuantitatif LC- MS/MS}

Identifikasi fraksi aktif biopigmen fukosantin dari sampel Padina sp. dan Sargassum sp. dengan pelarut aseton
80\% dianalisis menggunakan LC-MS/MS dengan sistem LC Ultra Performance Liquid Chromatoghrapy (UPLC) pada mode mass spectrometry ESI (Elektro Spray Ionization) dan QTOF (Quadrupole Time of Flight Mass). Eluen yang digunakan adalah air (A) dan asetonitril p.a (B). Eluen diatur pada laju aliran total $0,3 \mathrm{~mL} / \mathrm{menit}$. Hasil analisis yang didapat berupa kromatogram kemudian dianalisis menggunakan perangkat lunak masslynx. Perangkat lunak masslynx mengolah kromatogram menjadi berbentuk mass array. Mass array adalah bentuk matriks data tiga dimensi yang di dalamnya terdapat informasi massa akurat dari puncak yang terdeteksi, waktu retensi, dan intensitas puncak. Data yang didapatkan kemudian diidentifikasi dengan menentukan massa molekul $(\mathrm{m} / \mathrm{z})$ dan mencari rumus molekul kemudian membandingkannya dengan rumus molekul dari senyawa bioaktif yang terdapat pada Chemistry Structure Database (Chemspider) (www.chemspider.com). Hasil data berupa rumus molekul, bentuk molekul, massa molekul, dan kelimpahan senyawa yang dihitung berdasarkan luas area peak yang terdeteksi pada kromatogram.

Senyawa aktif yang terdeteksi pada sampel rumput laut terbagi dua yaitu senyawa pigmen dan non-pigmen. Senyawa aktif pigmen merupakan senyawa yang memberikan warna pada rumput laut. (Limantara dan Heriyanto 2011). Penentuan senyawa aktif pigmen dan non pigmen dari fraksi aktif fukosantin rumput laut Padina sp. dan Sargassum sp. dengan pelarut aseton $80 \%$ dapat dilihat pada Table 7.

Table 7 menunjukkan bahwa senyawa non pigmen lebih banyak terdeteksi dibandingkan senyawa pigmen. Hal ini disebabkan oleh sampel uji yang digunakan untuk analisis 
Table 7 Suspected active pigment and non-pigment compounds detected from fraction of fucoxanthin Sargassum sp. and Padina sp.

\begin{tabular}{|c|c|c|c|c|c|}
\hline Sample & $\begin{array}{l}\text { Retention } \\
\text { times } \\
\text { (minutes) }\end{array}$ & $\begin{array}{l}\text { Molecular } \\
\text { formula }\end{array}$ & $\begin{array}{c}\text { Molecular } \\
\text { mass } \\
(\mathrm{m} / \mathrm{z})\end{array}$ & Compound & $\begin{array}{c}\text { Identitication } \\
(\%))\end{array}$ \\
\hline \multirow{18}{*}{$\begin{array}{l}\text { Fraction of } \\
\text { Fucoxanthin } \\
\text { Sargassum sp. }\end{array}$} & \multicolumn{5}{|c|}{ Non-pigment Compound } \\
\hline & 0.95 & $\mathrm{C}_{9} \mathrm{H}^{4} \mathrm{O}_{7}$ & 225.0035 & 3,4-Dihyroxycyclohexanone & 88.49 \\
\hline & 9.32 & $\mathrm{C}_{14} \mathrm{H}_{26} \mathrm{O}_{13}$ & 403.1452 & L- $\alpha-\mathrm{D}-\mathrm{Hepp}-(1->3)-\mathrm{L}-\alpha-\mathrm{D}-\mathrm{Hepp}$ & 91.13 \\
\hline & 9.92 & $\mathrm{C}_{32} \mathrm{H}_{46} \mathrm{O}_{18}$ & 719.2762 & a-D-mannopyranoside & 95.49 \\
\hline & 10.53 & $\mathrm{C}_{32} \mathrm{H}_{48} \mathrm{O}_{18}$ & 721.2919 & $\beta$-D-glucopyranoside & 96.07 \\
\hline & 10.78 & $\mathrm{C}_{60} \mathrm{H}_{68} \mathrm{O}_{10}$ & 869.5145 & Cyclolanostane & 78.16 \\
\hline & 10.57 & $\mathrm{C}_{38} \mathrm{H}_{58} \mathrm{O}_{9}$ & 659.4159 & 3,6,16,25-tetrayl tetraacetate & 78.71 \\
\hline & 11.63 & $\mathrm{C}_{42} \mathrm{H}_{54} \mathrm{O}_{7}$ & 659.3948 & 6-propylbenzoate & 81.52 \\
\hline & 11.81 & $\mathrm{C}_{32} \mathrm{H}_{66} \mathrm{O}_{13}$ & 659.4582 & Propane-1,3-dioloctanoic acid & 78.54 \\
\hline & \multicolumn{5}{|c|}{ Pigment Compound } \\
\hline & 9.73 & $\mathrm{C}_{42} \mathrm{H}_{58} \mathrm{O}_{6}$ & 659.4312 & Fucoxanthin & 83.50 \\
\hline & 4.13 & $\mathrm{C}_{15} \mathrm{H}_{12} \mathrm{O}_{2}$ & 225.0916 & Flavanone & 95.72 \\
\hline & 10.57 & $\mathrm{C}_{21} \mathrm{H}_{22} \mathrm{O}_{8}$ & 403.1393 & Nobiletin & 78.09 \\
\hline & 9.32 & $\mathrm{C}_{40} \mathrm{H}_{60} \mathrm{O}$ & 557.4722 & Chloroxantin & 80.56 \\
\hline & 10.57 & $\mathrm{C}_{27} \mathrm{H}_{30} \mathrm{O}_{16}$ & 611.1612 & Rutin & 73.27 \\
\hline & 11.01 & $\mathrm{C}_{40} \mathrm{H}_{56} \mathrm{O}_{3}$ & 585.4308 & Flavoxantin & 78.23 \\
\hline & 11.01 & $\mathrm{C}_{40} \mathrm{H}_{56} \mathrm{O}_{3}$ & 585.4308 & Caloxantin & 78.23 \\
\hline & 11.01 & $\mathrm{C}_{40} \mathrm{H}_{56} \mathrm{O}_{3}$ & 585.4308 & Lutein & 78.23 \\
\hline \multirow{13}{*}{$\begin{array}{l}\text { Fraction of } \\
\text { Fucoxanthin } \\
\text { Padina sp. }\end{array}$} & \multicolumn{5}{|c|}{ Non-pigment Compound } \\
\hline & 0.8 & $\mathrm{C}_{10} \mathrm{H}_{21} \mathrm{NO}_{5}$ & 236.1498 & N-Butyl-D-glucopyranosylamine & 99.98 \\
\hline & 8.74 & $\mathrm{C}_{35} \mathrm{H}_{62} \mathrm{O}_{11}$ & 659.4370 & 4-O-methyl- $\beta$-D-xylopyranoside & 75.85 \\
\hline & 9.92 & $\mathrm{C}_{14} \mathrm{H}_{26} \mathrm{O}_{13}$ & 403.1452 & L- $\alpha$-D-Hepp-(1->3)-L- $\alpha-\mathrm{D}-\mathrm{Hepp}$ & 90.61 \\
\hline & 10.83 & $\mathrm{C}_{51} \mathrm{H}_{64} \mathrm{O}_{9}$ & 821.4629 & Tetraoxapentadecan & 81.00 \\
\hline & 12.11 & $\mathrm{C}_{21} \mathrm{H}_{18} \mathrm{O}_{3}$ & 403.1334 & Tetramethyl-phenyl & 79.20 \\
\hline & \multicolumn{5}{|c|}{ Pigment Compound } \\
\hline & 9.92 & $\mathrm{C}_{42} \mathrm{H}_{58} \mathrm{O}_{6}$ & 659.4312 & Fucoxanthin & 71.71 \\
\hline & 4.06 & $\mathrm{C}_{15} \mathrm{H}_{12} \mathrm{O}_{2}$ & 225.0916 & Flavanone & 85.22 \\
\hline & 12.11 & $\mathrm{C}_{27} \mathrm{H}_{30} \mathrm{O}_{16}$ & 611.1612 & Rutin & 73.27 \\
\hline & 10.83 & $\mathrm{C}_{40} \mathrm{H}_{56} \mathrm{O}_{3}$ & 585.4308 & Flavoxantin & 74.56 \\
\hline & 10.83 & $\mathrm{C}_{40} \mathrm{H}_{56} \mathrm{O}_{3}$ & 585.4308 & Caloxantin & 74.56 \\
\hline & 10.83 & $\mathrm{C}_{40} \mathrm{H}_{56} \mathrm{O}_{3}$ & 585.4308 & Lutein & 74.56 \\
\hline
\end{tabular}

Note: online source database from www.chemspider.com 
LC-MS/MS dalam bentuk fraksi berwarna oranye kecokelatan yang diduga memiliki senyawa pigmen aktif fukosantin. Dugaan tersebut terbukti dengan ditemukannya senyawa fukosantin pada hasil analisis dengan rumus molekul $\mathrm{C}_{42} \mathrm{H}_{58} \mathrm{O}_{6}$ yang memiliki massa molekul $659,4312 \mathrm{~m} / \mathrm{z}$ pada waktu retensi 9,73 menit pada sampel Sargassum sp. dan 9,92 menit pada sampel Padina sp. Penelitian Fernandes (2018) menunjukkan bahwa senyawa fukosantin dengan rumus molekul $\mathrm{C}_{42} \mathrm{H}_{58} \mathrm{O}_{6}$ memiliki massa molekul $658,4233 \mathrm{~m} / \mathrm{z}$ dengan waktu retensi 9,65 menit. Waktu retensi dan massa molekul hasil penelitian dan literatur tidak jauh berbeda, hal ini dapat dipengaruhi oleh selektivitas kerja LC-MS/MS terhadap sampel yang digunakan penelitian dalam bentuk fraksi sehingga lebih murni dibandingkan sampel oleh literatur dalam bentuk ekstrak kasar (Pan et al. 2012). Pada penelitian selanjutnya perlu dilakukan pengujian antioksidan dan SPF untuk fraksi non fukosantin (fraksi 1-5) serta uji stabilitas untuk fraksi fukosantin, perlu juga menambahkan analisis aktivitas antioksidan dengan mekanisme kerja secara in vivo.

\section{KESIMPULAN}

Fraksinasi rumput laut Padina sp. dan Sargassum sp. untuk menghasilkan fraksi aktif fukosantin paling optimal yaitu menggunakan pelarut aseton $80 \%$. Ekstraksi fraksi aktif fukosantin dengan pelarut aseton $80 \%$ menghasilkan rendemen, aktivitas antioksidan, total fenol, dan nilai SPF yang lebih baik dibandingkan menggunakan pelarut aseton 90\%. Hasil identifikasi profil komponen senyawa dengan analisis LCMS/MS juga membuktikan bahwa terdapat senyawa fukosantin pada hasil fraksi dengan rumus molekul $\mathrm{C}_{42} \mathrm{H}_{58} \mathrm{O}_{6}$ yang memiliki massa molekul 659,4312 m/z.

\section{DAFTAR PUSTAKA}

Apostolidis E, Lee CM. 2010. In vitro potential of Ascophyllum nodusum phenolic antioxidant-mediated alpha-glycosidase and alpha-amylase inhibition. Journal of Food Science. 75(3): 97-102.

Apak R, Guclu K, Ozyurek M, Celik SE. 2008. Mechanism of antioxidant capacity assays and the CUPRAC (cupric ion reducing antioxidant capacity) assay. Microchimica Acta.160: 413-419.

Arifianti AE, Anwar E, Nurjanah. 2017. Aktivitas penghambatan tirosinase dan antioksidan serbuk rumput laut dari Sargassum plagyophyllum segar dan kering. Jurnal Pengolahan Hasil Perikanan Indonesia. 20(3): 488-493

Badarinath AV, Rao KM, Chetty CMS, Ramkanth S, Rajan TVS, Gnanaprakash K. 2010. A review on in-vitro antioxidant methods: comparisons, correlations and considerations. International Journal of Pharmatech Research. 2(2): 1276-1285.

Boeing JS, Erica OB, Beatriz CS, Paula FM, Vitor CA, Jesui VV. 2014. Evalution of solvent effect on the extraction of phenolic compounds and antioxidant capacities from the barriers: Application of principal component analysis. Chemistry Central Journal. 8(48): 1-9.

[BPOM] Badan Pengawas Obat dan Makanan. 2004. Monograft Ekstrak Tumbuhan Obat Indonesia. Jakarta (ID): BPOM RI.

Dang TT, Bowyer MC, Altena IAV, Scarlett CJ. 2018. Comparison of chemical profile and antioxidant properties of the brown algae. International Journal of Food Science and Technology. 53: 174-181.

Denantica DP. 2012. Analisis faktor-faktor yang mempengaruhi ekspor rumput laut dan kajian trend volume ekspor rumput laut Indonesia ke China. [skripsi]. Bogor (ID): Institut Pertanian Bogor.

Departement of Health and Human Services. 2000. Report on Carcinogens Background Document for Broad-Spectrum Ultraviolet (UV) Radiation and UVA, UVB, and UVC. North Carolina (USA): Departement of Health and Human Services.

Diachanty S, Nurjanah, Abdullah A. 2017. Aktivitas antioksidan berbagai jenis rumput laut cokelat dari perairan Kepulauan Seribu. Jurnal Pengolahan Hasil Perikanan Indonesia. 20(2): 305318.

Dolorosa MT, Nurjanah, Purwaningsih S, Anwar E, Hidayat T. 2017. Kandungan senyawa bioaktif bubur rumput laut Sargassum plagyophyllum dan Eucheuma 
cottonii sebagai bahan baku krim pencerah kulit. Jurnal Pengolahan Hasil Perikanan Indonesia. 20(3): 633-644.

Egwaikhide PA, Gimba CE. 2007. Analysis of the phytochemical content and antimicrobial activity of Plectranthus glandulosis whole plant. Middle-East Journal of Scientific Reasearch. 2(3-4): 135-138.

Fernandes T. 2018. Karakterisasi dan identifikasi senyawa aktif ekstrak pigmen Sargassum polycystum dan Padina minor. [skripsi]. Bogor (ID): Institut Pertanian Bogor.

Fung AYC. 2012. The fucoxanthin content and antioxidant properties of Undaria pinnatifida from Marlborough Sound, New Zealand. [thesis]. Auckland University of Technology University.

Geraldino PJL, Liao LM, Boo SM. 2005. Morphologicl study of the marine algal genus Padina (Dictyotales, Phaeophyceae) from Southern Philippines : 3 species new to Philippines. Algae. 20(2): 99-112.

Javanmardi J, Stushnoff C, Lockeb E, Vivancob JM. 2003. Antioxidant activity and total phenolic content of iranian ocimum accessions. Food Chemistry. 83: 547-550.

Johnsen G, Lyssa P, Aamodt K. 2014. Sunscreen compositions comprising carotenoids. Foreign Application Priority Data. Patent Application Serial no. 051365.1. 1-21.

Khaled N, Hiba M, Asma C. 2012. Antioxidant and antifungal activities of Padina pavonica and Sargassum vulgare from the Lebanese Mediterranean Coast. Advances in Environmental Biology. 6(1): 42-48.

[KKP] Kementerian Kelautan dan Perikanan. 2014. Komoditas Rumput Laut Kian Strategis. [6 April 2014]. Diperoleh dari http://www.news.kkp.go.id- diakses pada 30 Juli 2018.

Kumar S, Sandhir R, Ojha S. 2014. Evaluation of antioxidant activity and total phenol in different varieties of Lantana camara leaves. BMC Research Notes. 7(560) : 1-9.

Lestari IL, Mita SR. 2017. Review : Potensi alga laut dan kandungan senyawa biologisnya sebagai bahan baku kosmeseutikal. Farmaka. 4(3): 1-15.

Limantara L, Heriyanto. 2010. Studi komposisi pigmen dan kandungan fukosantin rumput laut cokelat dari Perairan Madura dengan kromatografi cair kinerja tinggi. Ilmu Kelautan. 15(1): 23-32.

Limantara L, Heriyanto. 2011. Optimasi proses ekstraksi fukosantin rumput laut cokelat Padina australis Hauck menggunakan pelarut organic polar. Ilmu Kelautan. 16(2): 86-94.

Luthfiyana N, Nurjanah, Nurilmala M, Anwar E, Hidayat T. 2016. Rasio bubur rumput laut Euchema cottonii dan Sargassum sp. sebagai formula krim tabir surya. Jurnal Pengolahan Hasil Perikanan Indonesia. 19(3): 183-195.

Maharany F, Nurjanah, Suwandi R, Anwar E, Hidayat T. 2017. Kandungan senyawa bioaktif rumput laut Padina australis dan Euchema cottonii sebagai bahan baku krim tabir surya. Jurnal Pengolahan Hasil Perikanan Indonesia. 20(1): 10-17.

Narayani SS, Saravana S, Bharathiaraja S, Mahendran S. 2016. Extraction, partially purification and study on antioxidant property of fucoxanthin from Sargassum cinereum J. Agardh. Journal of Chemical and Pharmaceutical Research. 8(3): 610616.

Noviendri D, Jaswir I, Salleh MH, Taher M, Miyashita K, Ramli N. 2011a. Fucoxanthin extraction and fatty acid analysis of Sargassum binderi and $S$. duplicatum. Journal of Medicinal Plants Research. 5(11): 2405-2412.

Nurjanah, Aprilia BE, Fransiskayana A, Rahmawati M, Nurhayati T. 2018. Senyawa bioaktif rumput laut dan ampas teh sebagai antibakteri dalam formula masker wajah. Jurnal Pengolahan Hasil Perikanan Indonesia. 20(2): 304-316.

Nurjanah, Fauziyah S, Abdullah A. 2019. Karakteristik bubur rumput laut Eucheuma cottonii dan Turbinaria conoides sebagai bahan baku masker peel off. Jurnal Pengolahan Hasil Perikanan Indonesia. 22(2): 391-402.

Nurjanah, Nurilmala $M$, Luthfiyana $N$, Hidayat T. (2017). Identification of bioactive compounds of seaweed Sargassum sp. and Eucheuma cottonii doty as a raw sunscreen cream. Proceedings of 
the Pakistan Academy of Sciences: Part B. 54(4): 311-318.

Nursid M, Noviendri D, Rahayu L, Novelita V. 2016. Isolasi fukosantin dari rumput laut coklat Padina australis dan sitotoksisitasnya terhadap sel MCF7 dan sel vero. Jurnal Pascapanen dan Bioteknologi Kelautan dan Perikanan. 11(1): 83-90.

Pan RN, Kuo BPC, Pao LH. 2012. Validated LCMS-MS method for the determination of quetiapine in human plasma: application to a pharmacokinetic study. Journal of Chromatographic Science. 50: 277-282.

Petro AJ. 1981. Correlation of spectrophotometric data with sunscreen protection factor. International Journal of Cosmetic Sciences. 185-196.

Re R, Pellegrini N, Proteggente A, Pannala A, Yang M, Rice-Evans C. 1999. Antioxidant activity applying an improved ABTS radical cation-decolorizing assay. Free Radical Biology and Medicine. 26: 12311237.

Renhoran M, Noviendri D, Setyaningsih I, Uju. 2017. Ekstraksi dan purifikasi fukosantin dari Sargassum sp. sebagai anti-acne. Jurnal Pengolahan Hasil Perikanan Indonsesia. 20(2): 370-379.

Sami FJ, Nur S, Martani MM. 2015. Uji aktivitas tabir surya pada beberapa spesies dari family Zingiberaeae dengan metode spektrofotometri. As-Syifaa. 7(2): 164-173.

Seely GR, Duncan MJ, dan Vidaver WE. 1972. Preparative and analytical extraction of brown algae with dimethyl sulfoxide. Marine Biology. 12: 184-188.

Sudhakar MP, Ananthalakshmi JS, Nair BB. 2013. Extraction, purification, and study on antioxidant properties of fucoxanthin from brown seaweeds. Journal of Chemical and Pharmaceutical Research. 5(7): 169175.

Suryana WN. 2010. Optimasi ekstraksi sinensetin dari daun kumis kucing. [skripsi]. Bogor (ID) : Institut Pertanian Bogor.

Tang C. 1991. Phenolic Compound in Food. Washington (US): American Chemical Society.

Wahyuni DT, Widjanarko SB. 2015. Pengaruh jenis pelarut dan lama ekstraksi terhadap ekstrak karotenoid labu kuning dengan metode gelombang ultrasonic. Jurnal Pangan dan Agroindustri. 3(2): 390-401.

Widyastuti N. 2010. Pengukuran aktivitas antioksidan dengan metode CUPRAC, DPPH, dan FRAP serta korelasinya dengan fenol dan flavonoid pada enam tanaman. [skripsi]. Bogor (ID) : Institut Pertanian Bogor.

Wu HY, Lim SJ, Mustafha WAW, Maskat MY, Said M. 2014. Characterisation and stability of pigment extracted from Sargassum binderi obtained from Semporna, Sabah. Sains Malaysiana. 43(9): 1345-1354.

Yan X, Chuda Y, Suzuki M, Nagata T. 1999. Fucoxanthin as the major antioxidant in Hijika fusiformis a common edible seaweed. Bioscience, Biotechnology, and Biochemistry. 63(3) : 605-607.

Yanuarti R, Nurjanah, Anwar E, Hidayat T. 2017. Profil fenolik dan aktivitas antioksidan dari ekstrak rumput laut Turbinaria conoides dan Eucheuma cottonii. Jurnal Pengolahan Hasil Perikanan Indonesia. 20(2): 230-237 